\title{
Analisis Pengaruh Pemasangan Dynamic Voltage Restorer (DVR) terhadap Kedip Tegangan akibat Gangguan Hubung Singkat 3 Fasa pada Penyulang Kampus
}

\author{
I Gusti Agung Alit Teja Kusuma Putra ${ }^{1}$, I Wayan Rinas ${ }^{2}$, Yanu Prapto Sudarmojo ${ }^{3}$
}

\begin{abstract}
One of the disturbances that arise in the distribution of electric power is a 3 phase short circuit. 3-phase short circuit occurring in the distribution of electrical energy is not only causing a large fault currents on phases are impaired but also cause voltage sag on the distribution system. In general, voltage sag interference could result in damage/failure of equipment and disruption of network security equipment performance. This study analyzed the effect of the installation of Dynamic Voltage Restorer (DVR) on the voltage sag in the Kampus Feeder, using MATLAB-Simulink software, with a 3phase short circuit and 5 to load variations is the percentage of load of $50 \%, 55 \%, 60 \%, 65 \%$, and $70 \%$ of the total power distribution transformers to determine the effect of the DVR installation on each load. Based on the analysis the greater percentage of the load voltage sag disorder is also getting bigger, causing fundamental voltage on each phase decreases. The voltage drop can be recovered by the DVR by supplying the voltage at each voltage-dropping phase. DVR supply voltage up to 1 pu on each phase. At a load percentage of $50 \%$ the DVR supplies a voltage of 0.29 pu in phase $A, 0.24$ pu at phase $B$ and $0.29 \mathrm{pu}$ at phase $\mathrm{C}$.
\end{abstract}

Intisari- Salah satu gangguan yang timbul dalam pendistribusian tenaga listrik adalah gangguan hubung singkat 3 fasa. Gangguan hubung singkat 3 fasa yang terjadi dalam pendistribusian energi listrik tidak hanya menyebabkan timbulnya arus gangguan yang besar pada fasa-fasa yang mengalami gangguan akan tetapi juga menyebabkan kedip tegangan pada sistem distribusi. Secara umum gangguan kedip tegangan dapat mengakibatkan kerusakan/ kegagalan peralatan dan terganggunya kinerja peralatan pengaman jaringan. Penelitian ini menganalisis pengaruh pemasangan Dynamic Voltage Restorer (DVR) terhadap kedip tegangan di Penyulang Kampus, menggunakan software MATLAB-Simulink, dengan gangguan hubung singkat 3 fasa dan 5 variasi beban yaitu dengan persentase beban $50 \%, 55 \%, 60 \%, 65 \%$, dan $70 \%$ dari total daya trafo distribusi untuk mengetahui pengaruh pemasangan DVR pada setiap beban. Berdasarkan hasil analisis semakin besar persentase beban maka gangguan kedip tegangan juga semakin besar sehingga menyebabkan tegangan fundamental pada setiap fasa menurun. Penurunan tegangan dapat dipulihkan oleh DVR dengan menyuplai tegangan pada setiap fasa yang mengalami penurunan tegangan. DVR menyuplai tegangan hingga menjadi 1 pu pada setiap fasa. Pada

${ }^{1}$ Mahasiswa, Jurusan Teknik Elektro dan Komputer Fakultas Teknik Universitas Udayana, Jln. Cempaka, Dalung, Kuta Utara, Badung 80361 INDONESIA (tlp: 081237217098; e-mail: gungalitteja23@gmail.com)

${ }^{2,3}$ Dosen, Jurusan Teknik Elektro dan Komputer Fakultas Teknik Universitas Udayana, Jln. Kampus Bukit Jimbaran 80361 INDONESIA (telp: 0361-703315; fax: 0361-4321; e-mail: 'rinas@unud.ac.id, ${ }^{2}$ yanu.prapto@unud.ac.id, $)$ persentase beban sebesar 50\% DVR menyuplai tegangan sebesar 0,29 pu pada fasa $A, 0,24$ pu pada fasa $B$ dan 0,29 pu pada fasa C.

Kata kunci : Hubung Singkat 3 Fasa, Kedip Tegangan, Dynamic Voltage Restorer, Simulink Matlab.

\section{PENDAHULUAN}

Perkembangan teknologi yang sangat pesat menyebabkan semakin meningkatnya kebutuhan energi listrik. Agar dapat memenuhi kebutuhan tersebut maka diperlukan sistem distribusi yang baik. Sistem distribusi adalah sistem yang berfungsi menyalurkan tenaga listrik dari gardu induk ke konsumen. Banyaknya gangguan yang timbul dalam pendistribusian energi listrik dapat mengakibatkan menurunnya kualitas daya listrik. Salah satu gangguan yang timbul dalam pendistribusian tenaga listrik yaitu gangguan hubung singkat 3 fasa. Gangguan hubung singkat 3 fasa yang terjadi dalam pendistribusian energi listrik tidak hanya menyebabkan timbulnya arus gangguan yang besar pada fasafasa yang mengalami gangguan akan tetapi juga menyebabkan kedip tegangan pada sistem distribusinya.

Kedip tegangan adalah penurunan nilai rms tegangan pada frekuensi daya selama durasi waktu dari 0,5 cycles $(0,01$ detik) sampai 1 menit dan rentang perubahan dari 0,1 sampai 0,9 pu pada harga rms besaran tegangan [1]. Kedip tegangan dapat diakibatkan oleh: pembebanan yang besar pada sistem, gangguan hubung singkat, dan starting motor berdaya besar. Suatu sistem yang diberi beban yang besar akan mengalirkan arus yang melebihi arus pada beban nominal, hal ini menyebabkan terjadinya tegangan jatuh antara titik sumber dengan titik pembebanan. Besar nilai tegangan jatuh yang diakibatkan oleh kedip tegangan tergantung dari besar nilai impedansi titik pakai bersama $(\mathrm{PCC}=$ Point Common Coupling).

Hubung singkat adalah hubungan konduksi yang sengaja atau tidak sengaja melalui hambatan atau impedansi yang cukup rendah antara dua titik atau lebih yang dalam keadaan normalnya mempunyai beda potensial. Gangguan hubung singkat dapat disebabkan akibat hubungan kontak langsung dengan konduktor bertegangan, temperatur berlebih karena adanya arus berlebih (overload), pelepasan (discharge electron) yang merusak karena tegangan berlebih, busur (arcing) karena pengembunan bersama dengan udara terutama pada isolator [2].

Kedip tegangan berlangsung dalam waktu yang relatif singkat sehingga tidak diketahui dengan pasti saat terjadi gangguan. Gangguan kedip tegangan dapat menyebabkan trip 
peralatan- peralatan pengaman yang peka terhadap perubahan tegangan. Secara umum gangguan kedip tegangan dapat mengakibatkan motor tiba- tiba berhenti, peralatan digital terreset yang menyebabkan hilangnya data, kerusakan/ kegagalan peralatan dan terganggunya kinerja peralatan pengaman jaringan seperti beroperasinya sistem rele undervoltage yang akan menyebabkan pemutusan suplai tegangan pada jaringan sistem tenaga listrik.

Penyulang Kampus adalah penyulang dengan suplai tenaga listrik dari GI Nusa Dua yang terletak di wilayah Kuta Selatan. Penyulang ini memiliki konfigurasi sistem distribusi tipe radial, dengan panjang saluran 21,377 km. Gangguan hubung singkat pada penyulang dengan konfigurasi sistem radial menyebabkan terjadinya gangguan kedip tegangan pada busbar gardu induk. Selain itu, penyulang ini memiliki trafo distribusi sebanyak 57 buah dengan jumlah pelanggan sebanyak 7099 pelanggan. Gangguan kedip tegangan akan dirasakan oleh pelanggan yang disuplai dari transformator tegangan menengah dan tegangan rendah yang sama, maka dari itu kedip tegangan harus diantisipasi agar tidak terganggunya tegangan pada sisi beban.

\section{KEDIP TEGANGAN DAN DYNAMIC VOLTAGE RESTORER}

\section{A. Kedip Tegangan}

Pada umumnya kedip tegangan disebabkan karena gangguan hubung singkat dan karena pengasutan beban yang kapasitasnya cukup besar [3]. Kedip tegangan dapat menyebabkan menurunnya kualitas daya listrik. Konsumen menginginkan kualitas daya listrik yang diterima berada pada tingkat yang baik, oleh karena itu kedip tegangan harus diantisipasi dengan cepat untuk menghindari kerugian yang ditimbulkan oleh gangguan kedip tegangan.

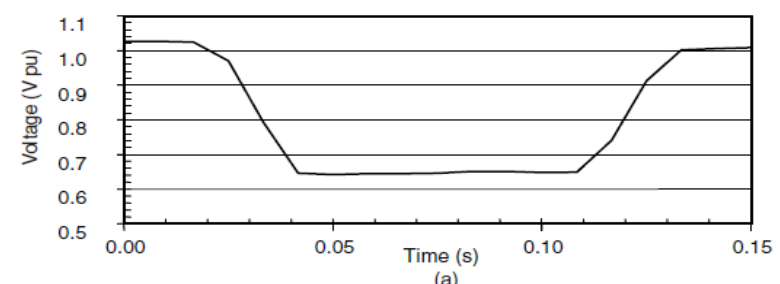

(a)

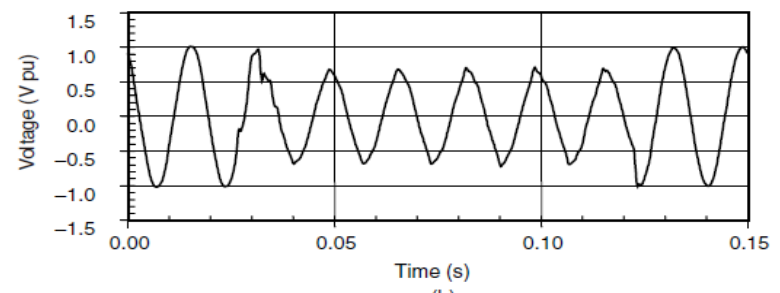

(b)

Gambar 1. Gangguan Kedip Tegangan akibat Gangguan Hubung Singkat Satu Fasa ke Tanah [4]

(a) Bentuk Gelombang RMS karena Gangguan Kedip Tegangan. (b) Bentuk Gelombang Kedip Tegangan.

\section{B. Dynamic Voltage Restorer (DVR)}

Dynamic Voltage Restorer (DVR) adalah suatu peralatan elektronika daya yang berfungsi untuk melindungi peralatan yang sensitif terhadap perubahan tegangan akibat gangguan kedip tegangan. Untuk mengatasi gangguan kedip tegangan, DVR menyuplai tegangan dinamik terkontrol untuk mengurangi pengaruh gangguan kedip tegangan pada bus yang mengalami gangguan kedip tegangan. Komponen dasar yang menyusun DVR adalah :

1. Voltage Source Converter (VSC)

VSC merupakan sebuah sistem elektronika daya yang terdiri dari peralatan penyimpanan dan pensaklaran, yang dapat membangkitkan tegangan listrik sinusoidal pada frekuensi dan sudut fasa yang diperlukan [5]. VSC berfungsi untuk mengkonversi tegangan DC menjadi tegangan AC yang dibutuhkan oleh transformator injeksi tegangan.

2. Sumber DC

Sumber DC berfungsi untuk menyediakan kebutuhan daya aktif selama terjadinya kompensasi oleh DVR dan juga berfungsi sebagai sumber tegangan input dari VSC. Sumber DC yang digunakan biasanya berupa baterai dan tenaga surya.

3. Transformator injeksi tegangan

Fungsi transformator injeksi adalah menaikkan tegangan supply AC yang dihasilkan oleh VSC menjadi tegangan yang dibutuhkan untuk memulihkan kedip tegangan [6].

4. Filter

Pada DVR biasanya menggunakan filter pasif. Penempatan filter pada sisi converter dapat mencegah orde harmonisa tidak mengalir melewati kumparan transformator namun filter tersebut menimbullkan tegangan drop dan pergeseran fasa pada (komponen fundamental) tegangan injeksi.

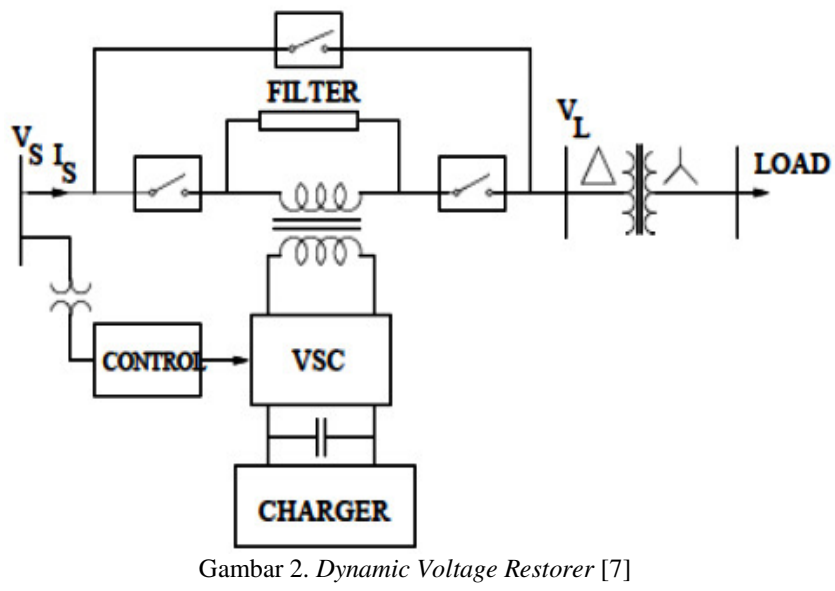

C. Hubung Singkat Tiga Fasa

Gangguan hubung singkat merupakan gangguan yang terjadi karena adanya kesalahan antara bagian- bagian yang bertegangan [8]. Gangguan hubung singkat tiga fasa merupakan gangguan simetris yang terjadi pada ketiga fasanya sehingga menyebabkan tegangan dan dan arus tetap seimbang setelah terjadinya gangguan.

I Gusti Agung Alit Teja Kusuma Putra : Analisis Pengaruh Pemasangan Dynamic... p-ISSN:1693 - 2951; e-ISSN: $2503-2372$ 
Gangguan hubung singkat tiga fasa yaitu ganggguan yang disebabkan oleh putusnya salah satu kawat fasa yang letaknya paling atas pada sistem transmisi atau sistem distribusi dengan konfigurasi kawat antar fasanya disusun secara vertikal [9]. Berikut merupakan gambar gangguan hubung singkat tiga fasa.

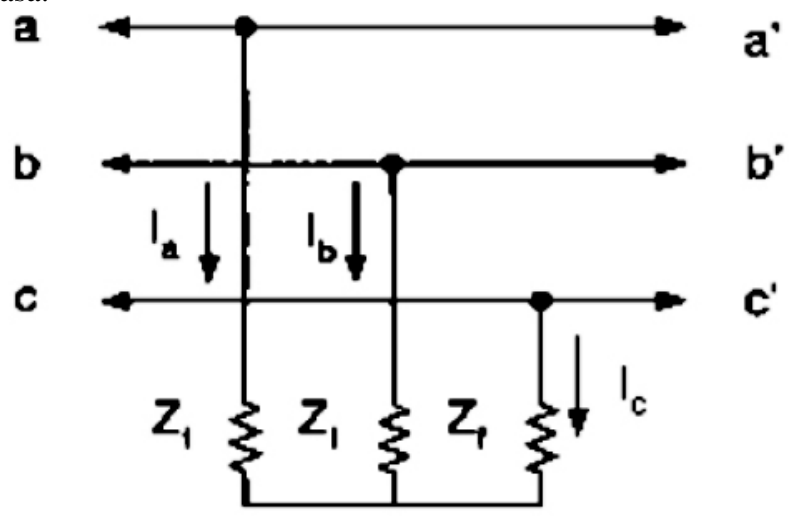

Gambar 3. Gangguan Hubung Singkat Tiga Fasa [10]

\section{PEMODELAN SIMULASI}

Data- data yang digunakan pada penelitian ini merupakan data sekunder yang diperoleh dari PT. PLN (Persero) Area Jaringan Bali Selatan yang beralamat di Jl. P.B Sudirman No.2 Denpasar. Adapun tahapan penelitian yang dilakukan adalah sebagai berikut :

1. Mengumpulkan data-data, antara lain: data transformator tenaga, data saluran distribusi dan data Penyulang Kampus.

2. Menghitung resistansi sumber dan induktansi sumber yang akan digunakan pada simulasi.

3. Pemodelan sistem Penyulang Kampus pada Program Simulink MATLAB.

4. Menentukan parameter-parameter yang digunakan pada simulasi.

5. Simulasi kondisi di Penyulang Kampus pada saat tidak terjadi gangguan kedip tegangan dengan menggunakan program Simulink MATLAB.

6. Simulasi terjadinya gangguan kedip tegangan dengan beban yang divariasikan dan gangguan hubung singkat 3 phase.

7. Simulasi pemulihan kedip tegangan dengan menggunakan DVR

8. Analisis pengaruh pemasangan DVR terhadap gangguan kedip tegangan berdasarkan hasil simulasi dan menarik kesimpulan.

\section{A. Pemodelan Simulasi}

Single line diagram Penyulang Kampus dapat dilihat pada Lampiran Gambar 4. Penempatan DVR pada simulasi yaitu dipasang seri antara sumber dan beban. Perangkat lunak Simulink MATLAB digunakan untuk simulasi pada penelitian ini. Model simulasi yang dibuat yaitu:

1. Model simulasi pada saat tidak terjadi gangguan kedip tegangan pada Penyulang Kampus.
Model simulasi pada saat tidak terjadi gangguan kedip tegangan dapat dilihat pada Lampiran Gambar 5.

2. Model Simulasi gangguan kedip tegangan pada penyulang kampus.

Model simulasi kedip tegangan adalah akibat dari gangguan hubung singkat 3 fasa. Model simulasi kedip tegangan dapat dilihat pada Lampiran Gambar 6.

3. Model simulasi pemulihan kedip tegangan dengan pemasangan DVR.

Model simulasi pemulihan kedip tegangan dengan pemasangan DVR dapat dilihat pada Lampiran Gambar 7. Pada Lampiran Gambar 7 simulasi pemulihan gangguan kedip tegangan menggunakan PI (Proportional Integral) controler sebagai pengendali DVR. DVR pada Lampiran Gambar 7 dipasang seri, yaitu antara sumber dan beban.

4. Pemodelan sumber 3 fasa

Data yang digunakan sebagai input pada blok parameter sumber 3 fasa adalah data teknik transformator distribusi.

5. Pemodelan beban

Beban yang digunakan pada simulasi ini merupakan beban pada penyulang kampus. Input data pada blok parameter beban yang digunakan pada simulasi yaitu data daya aktif $(\mathrm{P})$, daya reaktif $(\mathrm{Q})$, tegangan (Vrms), dan frekuensi.

\section{IV.HASIL DAN PEMBAHASAN}

\section{A. Hasil Simulasi}

Simulasi yang digunakan pada penelitian ini menggunakan 3 jenis simulasi yaitu :

1. Simulasi tanpa gangguan kedip tegangan

2. Simulasi gangguan kedip tegangan

3. Simulasi pemulihan kedip tegangan dengan memasang DVR

Simulasi gangguan kedip tegangan dan pemulihan kedip tegangan dilakukan dengan 5 variasi beban dan dengan gangguan hubung singkat 3 fasa. Simulasi dilakukan dengan periode gelombang $\mathrm{T}=0,12$ dan gangguan kedip tegangan yang terjadi diasumsikan mulai dari 0,04 detik sampai 0,08 detik.

\section{B. Hasil Simulasi tanpa Gangguan}

Simulasi tanpa gangguan kedip tegangan dilakukan untuk mengetahui bentuk gelombang tegangan jika tidak ada gangguan kedip tegangan di penyulang kampus. Hasil simulasi tanpa gangguan kedip tegangan dapat dilihat pada Lampiran Gambar 8.

C. Hasil Simulasi Gangguan Kedip Tegangan dan Pemulihan Kedip Tegangan

Simulasi gangguan kedip tegangan dan pemulihan kedip tegangan dilakukan pada beban 4.822,50 kVA (50\%), 5.304,75 kVA (55\%), $5.787 \mathrm{kVA}$ (60\%), 6.269,25 kVA $(65 \%)$, dan $6.751,50 \mathrm{kVA}(70 \%)$ dengan daya aktif dan reaktif seperti pada TABEl I dengan gangguan hubung singkat 3 fasa. Gangguan kedip tegangan yang terjadi diasumsikan mulai dari 0,04 detik sampai 0,08 detik dan resistansi gangguan diasumsikan sebesar $10 \Omega$. 
TABEL I

DAYA AKTIF (P) DAN DAYA REAKTIF (Q)

\begin{tabular}{|l|c|r|c|}
\hline No & Persentase Beban & \multicolumn{1}{c|}{ Daya Aktif (P) } & \multicolumn{1}{l|}{ Daya Reaktif (Q) } \\
\hline 1 & $50 \%$ & $4.099,125 \mathrm{~kW}$ & $2.540 .409,511$ VAR \\
\hline 2 & $55 \%$ & $4.509,038 \mathrm{~kW}$ & $2.794 .450,462$ VAR \\
\hline 3 & $60 \%$ & $4.918,950 \mathrm{~kW}$ & $3.048 .491,413$ VAR \\
\hline 4 & $65 \%$ & $5.328,863 \mathrm{~kW}$ & $3.302 .532,365$ VAR \\
\hline 5 & $70 \%$ & $5.738,775 \mathrm{~kW}$ & $3.556 .573,316$ VAR \\
\hline
\end{tabular}

Hasil simulasi gangguan kedip tegangan dan pemulihan kedip tegangan pada beban 4.822,50 kVA (50\%) dapat dilihat pada Lampiran Gambar 9.

Pada Lampiran Gambar 9 (a) dapat dilihat bahwa fasa A, $\mathrm{B}$ dan $\mathrm{C}$ mengalami kedip tegangan selama 0,04 detik yaitu dari 0,04 detik sampai 0,08 detik. Pada Lampiran Gambar 9 (b) terlihat fasa A, B, dan C kembali normal setelah dipasang DVR. DVR menyuplai tegangan pada fasa A, B dan C ketika mengalami penurunan tegangan, sehingga kedip tegangan tidak dirasakan pada sisi beban.

Kedip tegangan menyebabkan turunnya tegangan pada setiap fasa yang mengalami gangguan. Besar nilai tegangan pada setiap fasa yang mengalami gangguan kedip tegangan dapat diketahui dengan menggunakan bantuan FFT tools yang ada pada MATLAB Simulink. Berikut merupakan tampilan FFT tools gelombang tegangan pada beban $4.822,50 \mathrm{kVA}$ $(50 \%)$.

1. Gelombang Tegangan Fasa A
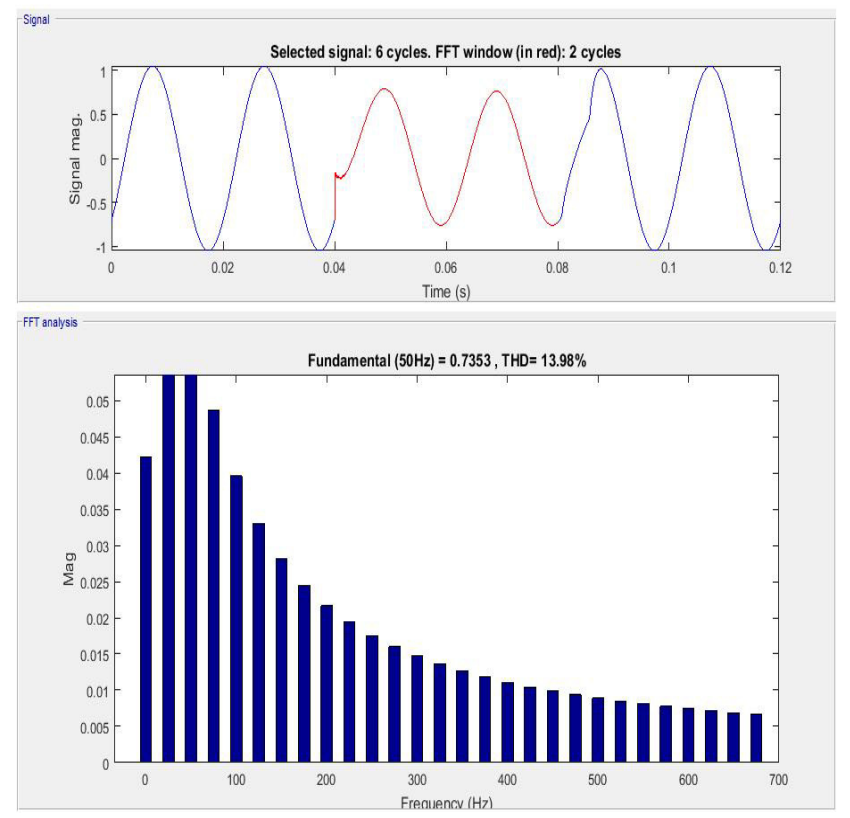

Gambar 10. FFT analisis gelombang tegangan fasa A tanpa DVR

Pada Gambar 10 dapat dilihat tegangan fundamental mengalami penurunan menjadi 0,7353 pu pada durasi waktu 0,04 detik sampai 0,08 detik dengan THDv sebesar 13,98\%. Hal ini disebabkan karena gangguan kedip tegangan yang terjadi.

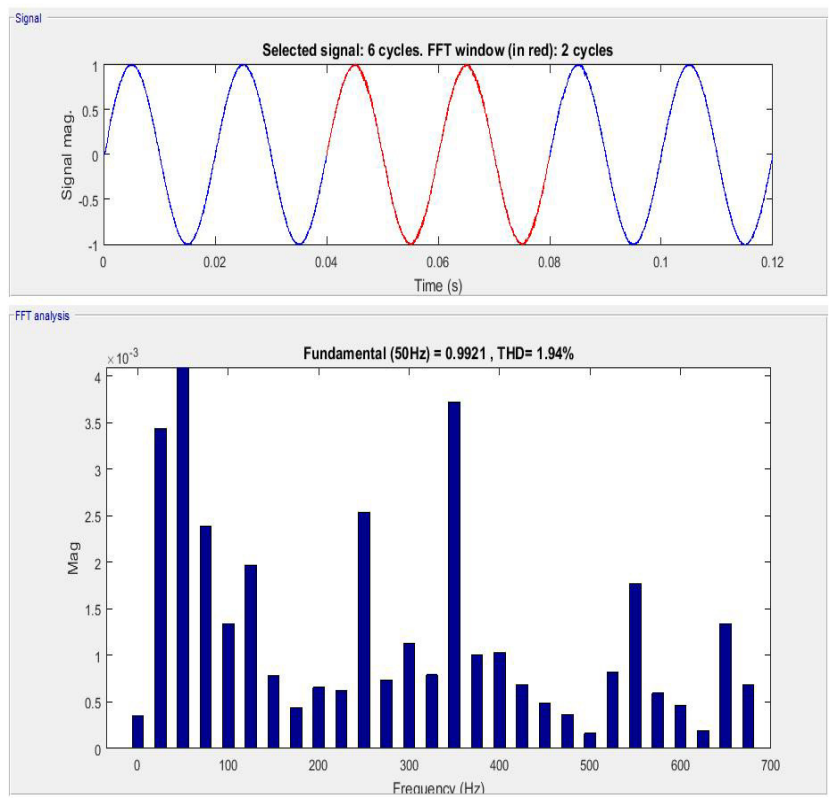

Gambar 11. FFT analisis gelombang tegangan fasa A setelah dipasang DVR

Pada Gambar 11 merupakan gambar gelombang fasa A setelah dipasang DVR. Pada Gambar 11 dapat dilihat tegangan fundamental naik menjadi 0,9921 pu dan THDv menurun menjadi $1,94 \%$.

2. Gelombang Tegangan Fasa B
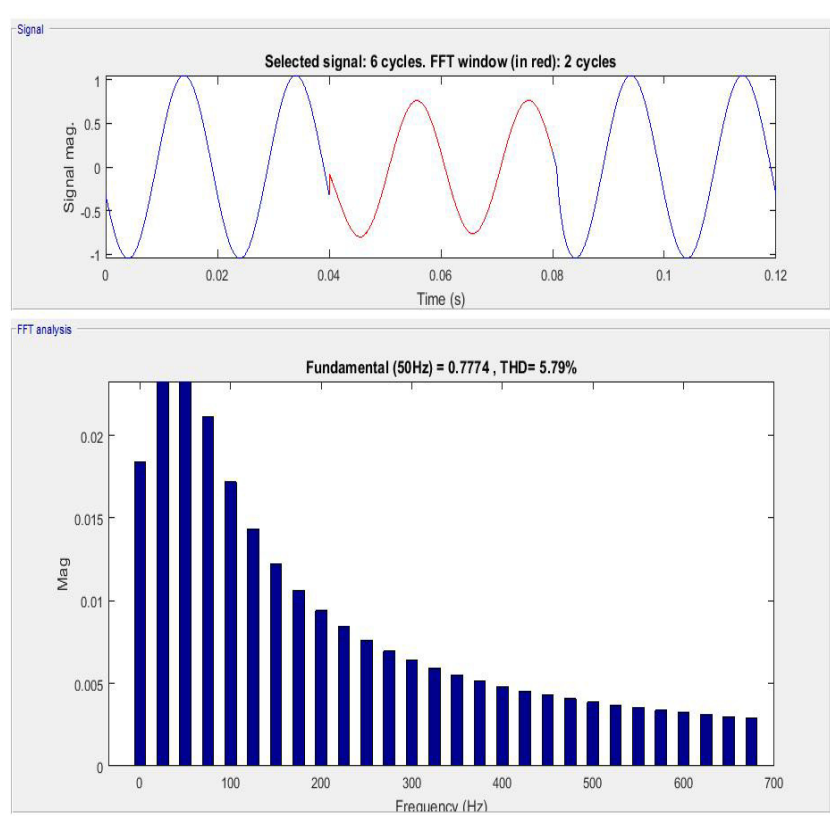

Gambar 12. FFT analisis gelombang tegangan fasa B tanpa DVR

Pada Gambar 12 dapat dilihat tegangan fundamental mengalami penurunan menjadi 0,7774 pu pada durasi waktu 0,04 detik sampai 0,08 detik dengan THDv sebesar

I Gusti Agung Alit Teja Kusuma Putra : Analisis Pengaruh Pemasangan Dynamic... p-ISSN:1693 - 2951; e-ISSN: $2503-2372$ 
$5,79 \%$. Hal ini disebabkan karena gangguan kedip tegangan yang terjadi.
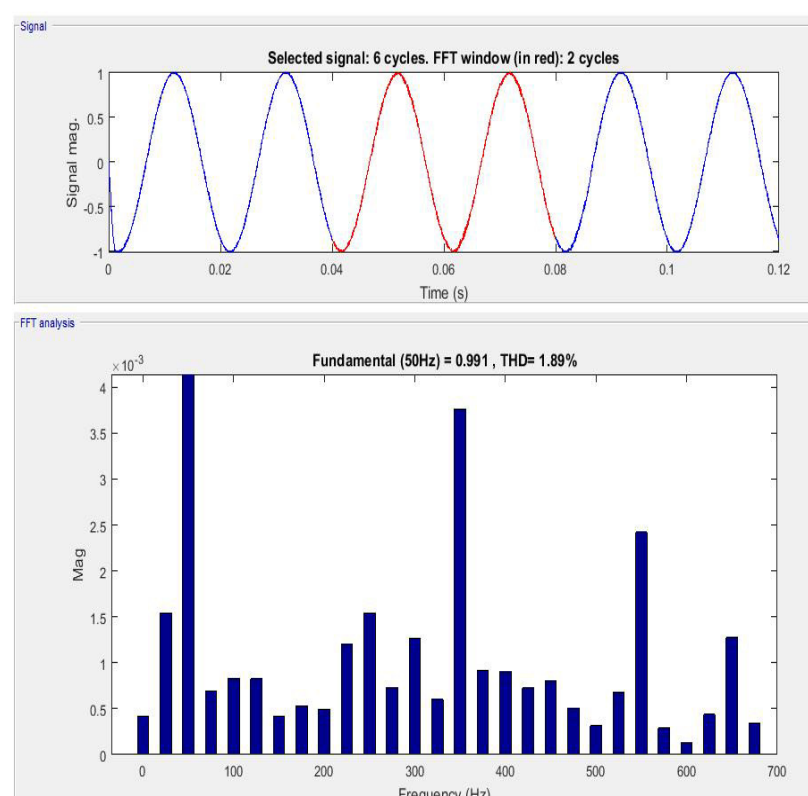

Gambar 13. FFT analisis gelombang tegangan fasa B setelah dipasang DVR

Pada Gambar 13 merupakan gambar gelombang fasa B setelah dipasang DVR. Pada Gambar 13 dapat dilihat tegangan fundamental naik menjadi 0,991 pu dan THDv menurun menjadi $1,89 \%$.

3. Gelombang Tegangan Fasa C
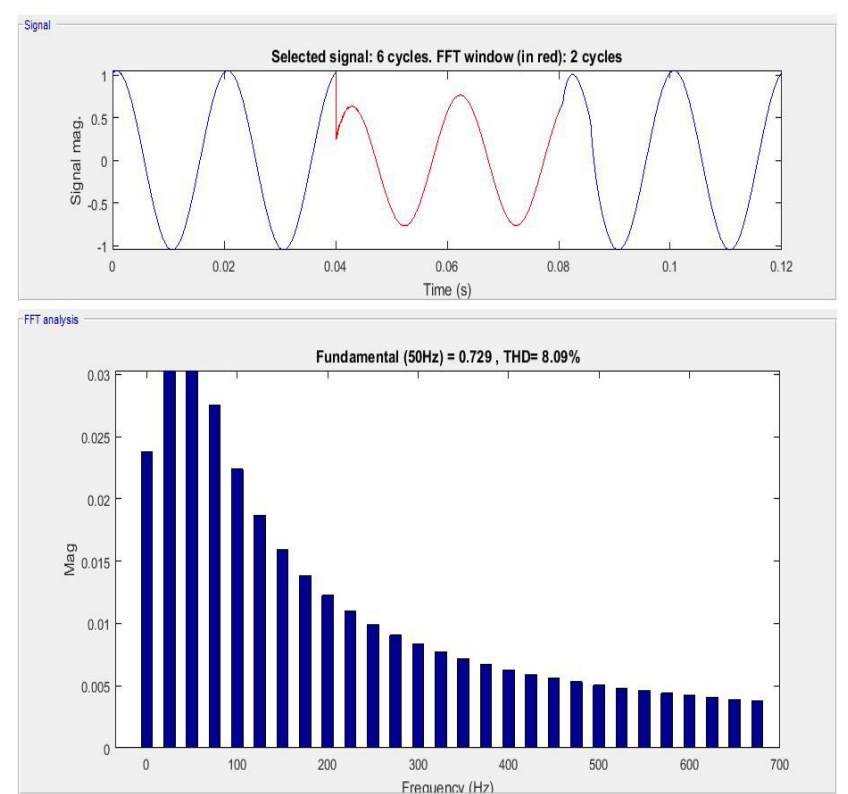

Gambar 14. FFT analisis gelombang tegangan fasa C tanpa DVR
Pada Gambar 14 dapat dilihat tegangan fundamental mengalami penurunan menjadi 0,729 pu pada durasi waktu 0,04 detik sampai 0,08 detik dengan THDv sebesar 8,09\%. Hal ini disebabkan karena gangguan kedip tegangan yang terjadi.
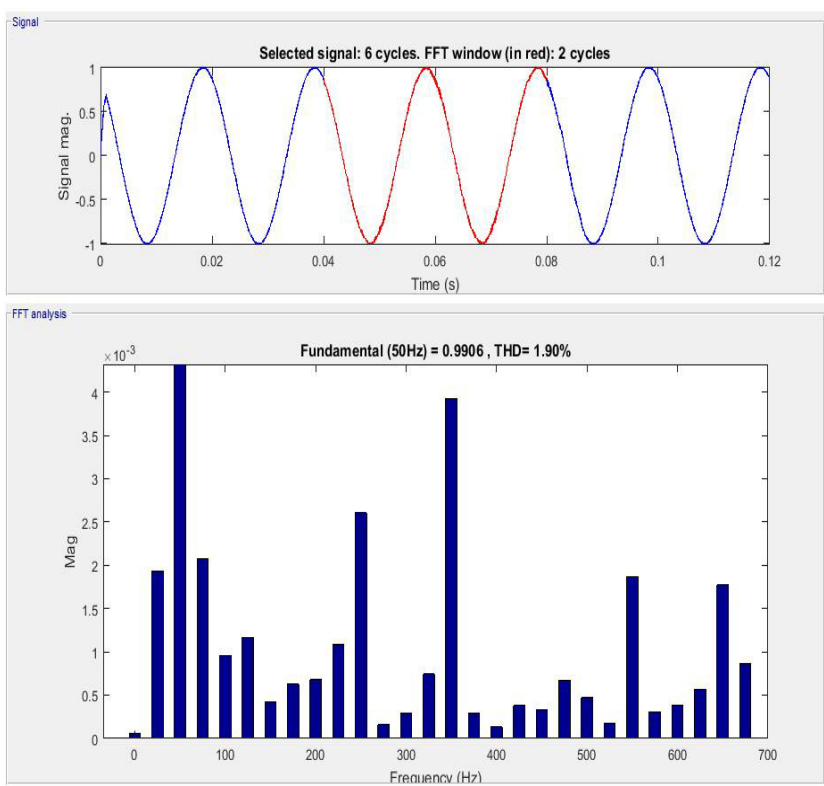

Gambar 15. FFT analisis gelombang tegangan fasa C setelah dipasang DVR

Pada Gambar 15 merupakan gambar gelombang fasa C setelah dipasang DVR. Pada Gambar 15 dapat dilihat tegangan fundamental naik menjadi 0,9906 pu dan THDv menurun menjadi $1,90 \%$.

Hasil simulasi kedip tegangan pada beban $4.822,50 \mathrm{kVA}$ (50\%) dapat dilihat pada tabel II.

TABEL II

HASIL SIMULASI PADA BEBAN 4.822,50 KVA (50\%)

\begin{tabular}{|c|c|c|c|c|c|}
\hline \multirow{2}{*}{ Fasa } & \multicolumn{2}{|c|}{ Vfundamental (pu) } & \multicolumn{2}{|c|}{ THDv (\%) } & \multirow{2}{*}{$\begin{array}{c}\text { V suplai } \\
\text { (pu) }\end{array}$} \\
\cline { 2 - 5 } & $\begin{array}{c}\text { Tanpa } \\
\text { DVR }\end{array}$ & DVR & $\begin{array}{c}\text { Tanpa } \\
\text { DVR }\end{array}$ & DVR & \\
\hline A & 0,7353 & 0,9921 & 13,98 & 1,94 & 0,2568 \\
\hline B & 0,7774 & 0,991 & 5,79 & 1,89 & 0,2147 \\
\hline C & 0,729 & 0,9906 & 8,09 & 1,90 & 0,2616 \\
\hline
\end{tabular}

D. Analisis Hasil Simulasi

Berdasarkan hasil simulasi kedip tegangan pada persentase beban $50 \%, 55 \%, 60 \%, 665 \%$, dan $70 \%$ dapat dilihat bahwa DVR mampu mengurangi THDv dan memulihkan tegangan akibat kedip tegangan dengan menyuplai tegangan pada fasa yang mengalami gangguan kedip tegangan. Untuk lebih jelasnya dapat dilihat pada tabel III dan tabel IV.

ISSN 1693 - 2951; e-ISSN: 2503-2372 I Gusti Agung Alit Teja Kusuma Putra : Analisis Pengaruh Pemasangan Dynamic ... 
TABEL III

KANDUNGAN THD SETIAP FASA PADA BEBAN 4.822,50 KVA (50\%), 5.304,75VA (55\%), 5.787 KVA (60\%), 6.269,25 KVA (65\%), DAN 6.751,50 $\operatorname{KVA}(70 \%)$

\begin{tabular}{|c|c|c|c|c|c|c|}
\hline \multirow{2}{*}{$\begin{array}{c}\text { Beban } \\
(\%)\end{array}$} & \multicolumn{2}{|c|}{ THDv (\%) Tanpa DVR } & \multicolumn{3}{|c|}{ THDv (\%) Dengan DVR } \\
\cline { 2 - 7 } & A & B & C & A & B & C \\
\hline 50 & 13,98 & 5,79 & 8,09 & 1,94 & 1,89 & 1,9 \\
\hline 55 & 13,62 & 5,89 & 7,61 & 1,95 & 1,93 & 1,92 \\
\hline 60 & 13,27 & 5,97 & 7,15 & 1,93 & 1,88 & 1,88 \\
\hline 65 & 12,92 & 6,03 & 6,73 & 1,99 & 1,94 & 1,85 \\
\hline 70 & 12,59 & 6,08 & 6,34 & 1,97 & 1,89 & 1,86 \\
\hline
\end{tabular}

Pada tabel III dapat dilihat bahwa kandungan THDv pada setiap fasa berkurang. Hal ini disebabkan oleh filter pasif yang ditempatkan pada sisi keluaran VSC (Voltage Source Converter) telah mereduksi THDv.

TABEL IV

HASIL SIMULASI PADA BEBAN 4.822,50 KVA, 5.304,75 KVA, 5.787 KVA, 6.269,25 KVA, DAN 6.751,50 KVA.

\begin{tabular}{|c|c|c|c|c|c|c|c|c|c|}
\hline \multirow{2}{*}{\begin{tabular}{|c|c}
$\mathbf{B}$ \\
$\mathbf{E}$ \\
$\mathbf{B}$ \\
$\mathbf{A}$ \\
$\mathbf{N}$ \\
$(\%)$
\end{tabular}} & \multicolumn{3}{|c|}{$\begin{array}{l}\text { V fundamental (pu) } \\
\text { Tanpa DVR }\end{array}$} & \multicolumn{3}{|c|}{$\begin{array}{c}\text { V fundamental } \\
\text { (pu) } \\
\text { Dengan DVR }\end{array}$} & \multicolumn{3}{|c|}{ V suplai (pu) } \\
\hline & $\mathbf{A}$ & B & $\mathbf{C}$ & $\mathbf{A}$ & B & C & $\mathbf{A}$ & B & C \\
\hline 50 & 0,73 & 0,78 & 0,73 & 0,9 & 0,9 & 0,9 & 0,26 & 0,21 & 0,26 \\
\hline 55 & 0,72 & 0,76 & 0,72 & 0,9 & 0,9 & 0,9 & 0,27 & 0,23 & 0,27 \\
\hline 60 & 0,71 & 0,75 & 0,71 & 0,9 & 0,9 & 0,9 & 0,28 & 0,24 & 0,28 \\
\hline 65 & 0,70 & 0,74 & 0,70 & 0,9 & 0,9 & 0,9 & 0,29 & 0,25 & 0,29 \\
\hline 70 & 0,69 & 0,72 & 0,69 & 0,9 & 0,9 & 0,9 & 0,30 & 0,26 & 0,30 \\
\hline
\end{tabular}

Pada tabel IV dapat dilihat bahwa semakin besar persentase beban maka tegangan fundamental pada setiap fasa menurun. Hal ini disebabkan karena gangguan kedip tegangan yang semakin besar. Penurunan tegangan dapat dipulihkan oleh DVR dengan menyuplai tegangan pada setiap fasa yang mengalami penurunan tegangan. Pada persentase beban sebesar 50\% terlihat DVR menyuplai tegangan sebesar 0,26 pu pada fasa A, 0,21 pu pada fasa B dan 0,26 pu pada fasa C. Pada persentase beban sebesar 55\% terlihat DVR menyuplai tegangan sebesar 0,27 pu pada fasa $A, 0,23$ pu pada fasa $\mathrm{B}$ dan 0,27 pu pada fasa C. Pada persentase beban sebesar $60 \%$ terlihat DVR menyuplai tegangan sebesar 0,28 pu pada fasa A, 0,24 pu pada fasa $\mathrm{B}$ dan 0,28 pu pada fasa C. Pada persentase beban sebesar $65 \%$ terlihat DVR menyuplai tegangan sebesar 0,29 pu pada fasa A, 0,25 pu pada fasa B dan 0,29 pu pada fasa C. Pada persentase beban sebesar $70 \%$ terlihat DVR menyuplai tegangan sebesar 0,30 pu pada fasa A, 0,26 pu pada fasa B dan 0,30 pu pada fasa C. DVR mampu memulihkan tegangan setiap fasa yang mengalami gangguan menjadi $1 \mathrm{pu}$.

\section{SIMPULAN}

Berdasarkan hasil pembahasan dapat disimpulkan bahwa DVR mampu memulihkan gangguan kedip tegangan pada penyulang kampus akibat gangguan hubung singkat 3 fasa dan beban yang bervariasi. DVR memulihkan tegangan menjadi 1pu pada fasa yang mengalami gangguan kedip tegangan. DVR memulihkan tegangan dengan menyuplai tegangan pada fasa yang mengalami gangguan. Pada hasil simulasi pemulihan kedip tegangan dengan persentase beban sebesar $50 \%$ terlihat DVR menyuplai tegangan sebesar 0,26 pu pada fasa A, 0,21 pu pada fasa B dan 0,26 pu pada fasa $C$.

\section{REFERENSI}

[1] IEEE Standard 1159-1995. Power Quality Monitoring. IEEE Standard Boards.

[2] IEC 60909.Short-Circuit Currents in Three-Phase A.C. Systems.

[3] M. W. N. Sabara, T. Yuwono, O. Penangsang, "Pengaruh Kedip Tegangan dan Koordinasi Rele Arus Lebih pada Pabrik Semen", JURNAL TEKNIK ITS Vol. 1, No. 1, (Sept. 2012) ISSN: 23019271.

[4] R.C. Dugan, M.F. McGranaghan, S. Santoso, H.W. Beaty, Electrical Power System Quality-Second Edition. The McGraw-Hill, 2004.

[5] Winarso, "Perbaikan Kualitas Tegangan Menggunakan Dynamic Voltage Restorer (Dvr)" Jurnal Ilmiah Foristek Vol.3, No. 1, Maret 2013.

[6] I. M. Y. Dwipayana “ Analisis Kedip Tegangan Akibat Gangguan Hubung Singkat Pada Penyulang Abang Di Karangasem" E-Journal SPEKTRUM Vol. 3, No. 2 Desember 2016.

[7] K. R. Padiyar, "Facts Controllers In Power Transmission and Distribution". New Age International, 2007.

[8] B. Indra, Sukerayasa, dan Ariastina, "STUDI KOORDINASI PERALATAN PROTEKSI OCRDANGFR PADA PENYULANG TIBUBENENG", Teknologi Elektro, Vol. 14, No. 2, pp. 50-56, JuliDesember. 2015

[9] M. B. Nurcahyadi, I. W. Rinas, A. A. G. M. Pemayun, "Analisis Sistem Pengaman Arus Lebih pada Penyulang Abang Akibat Beroperasinya PLTS pada Saluran Distribusi Tegangan Listrik 20 Kv di Karangasem" Teknologi Elektro, Vol. 16, No1, Januari-April 2017.

[10] J. C. Das, Power System Analysis, Short-Circuit Load Flow and Harmonics. United States of America : Marcel Dekker, 2002.

I Gusti Agung Alit Teja Kusuma Putra : Analisis Pengaruh Pemasangan Dynamic... p-ISSN:1693 - 2951; e-ISSN: $2503-2372$

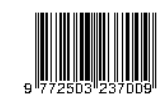


LAMPIRAN

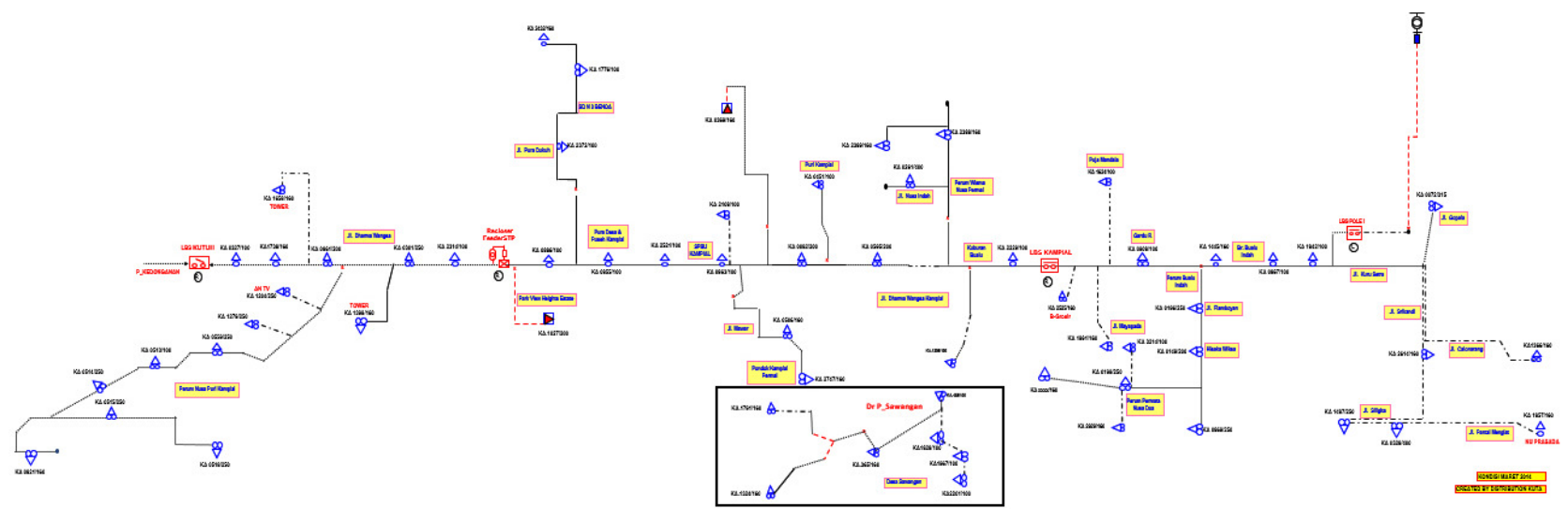

Gambar 4. Single line diagram penyulang kampus

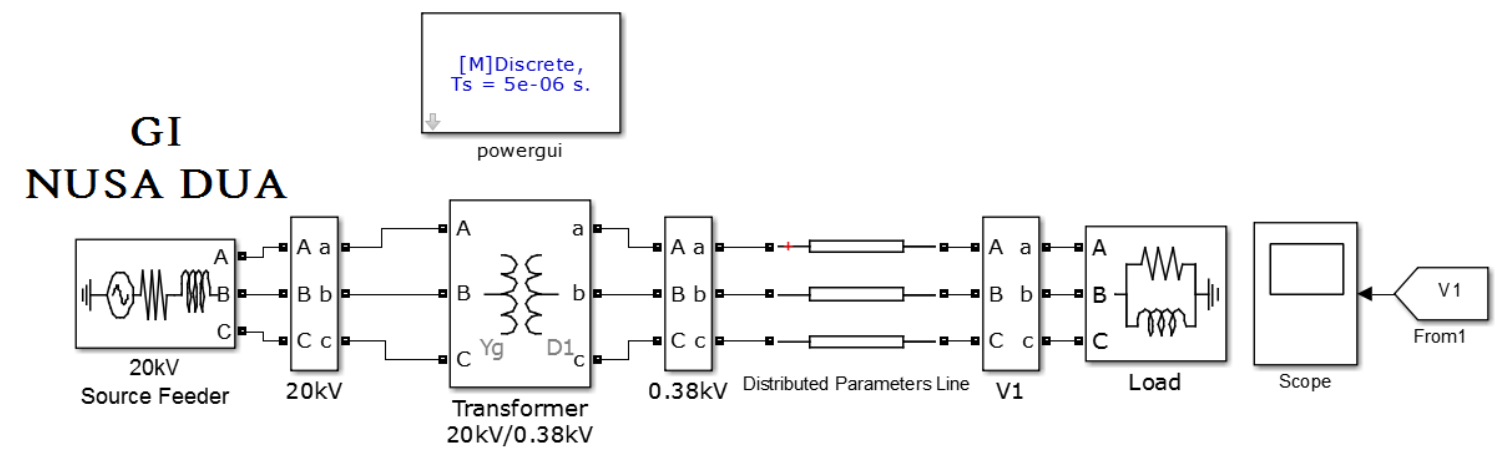

Gambar 5. Pemodelan pada saat tidak terjadi gangguan kedip tegangan

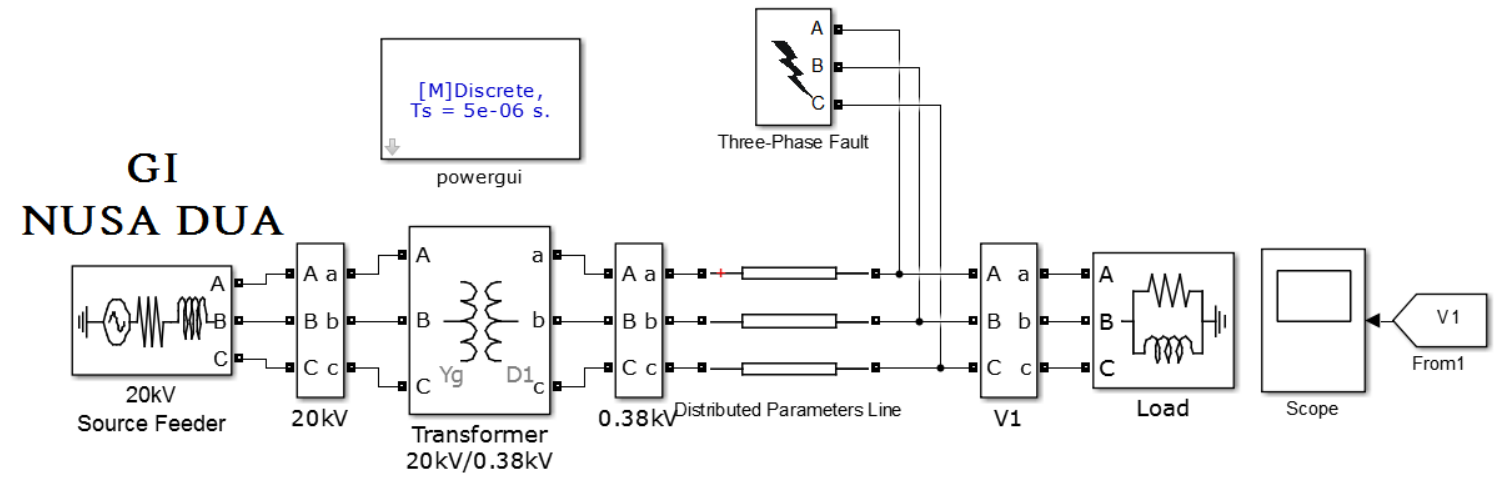

Gambar 6. Pemodelan simulasi gangguan kedip tegangan pada penyulang kampus

ISSN 1693 - 2951; e-ISSN: 2503-2372 I Gusti Agung Alit Teja Kusuma Putra : Analisis Pengaruh Pemasangan Dynamic ... 


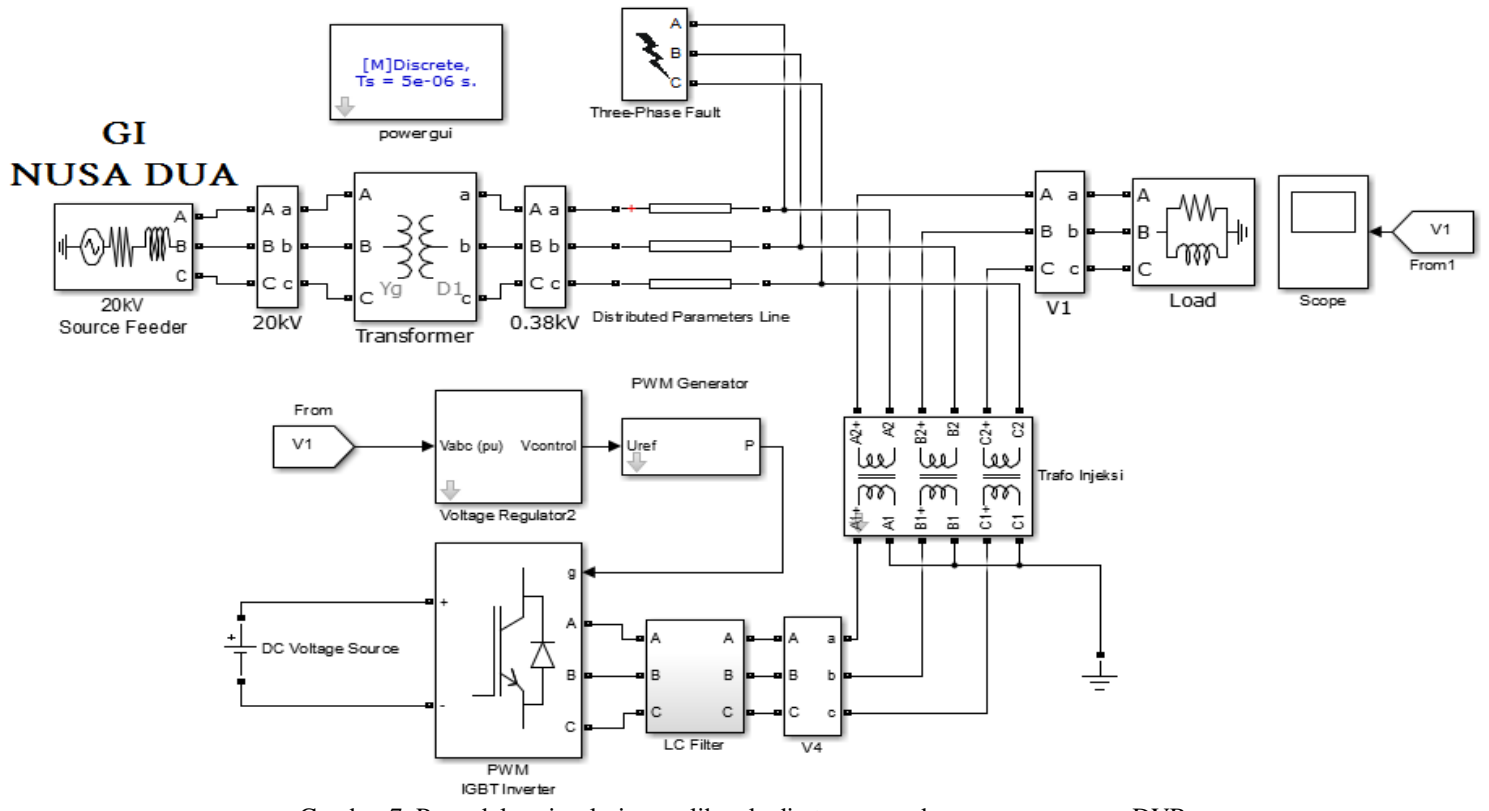

Gambar 7. Pemodelan simulasi pemulihan kedip tegangan dengan pemasangan DVR
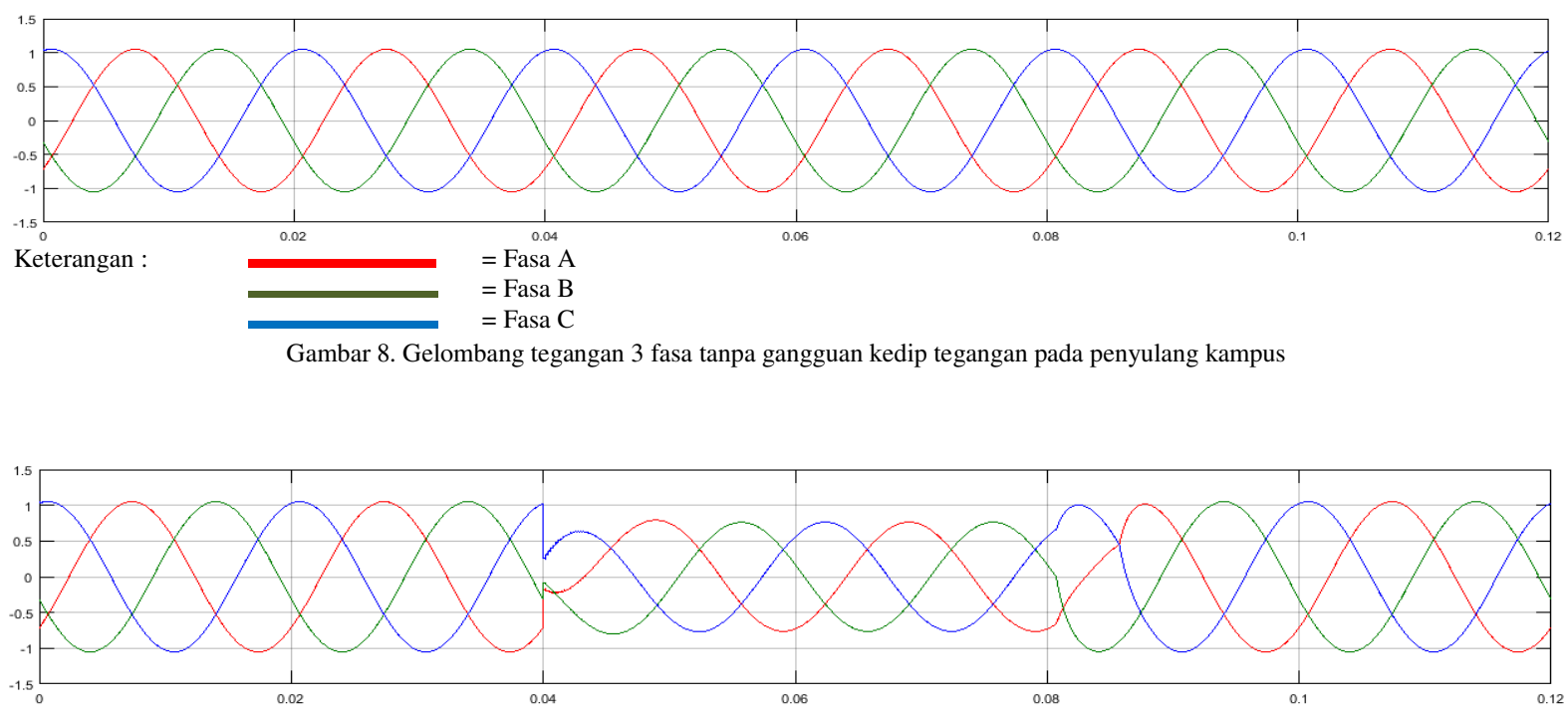

(a) Gelombang tegangan 3 fasa akibat kedip tegangan
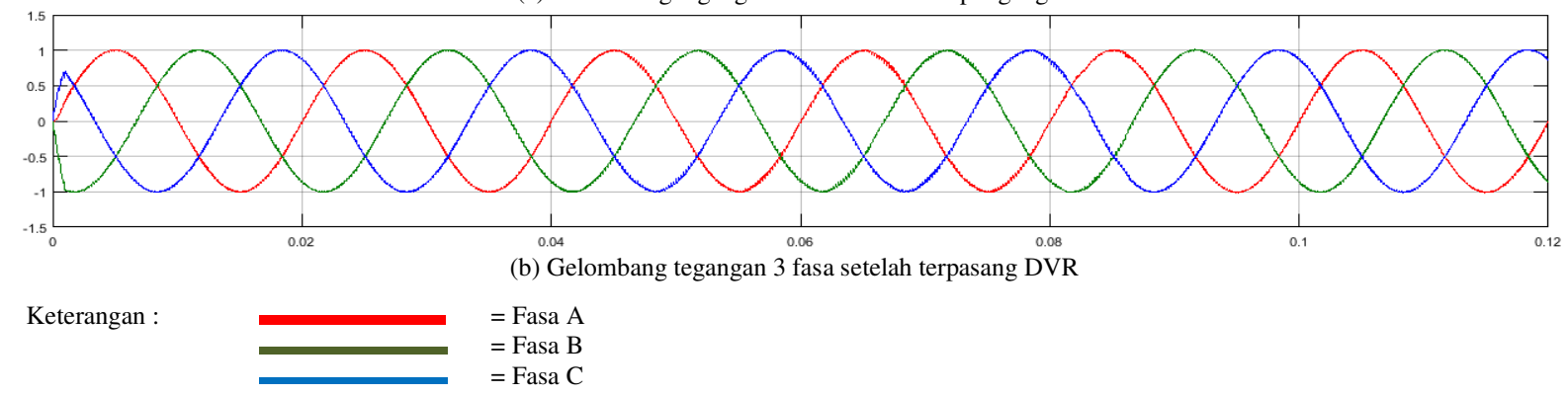

Gambar 9. Hasil simulasi gangguan kedip tegangan dan pemulihan kedip tegangan dengan beban 4.822,50 kVA (50\%) pada penyulang kampus

I Gusti Agung Alit Teja Kusuma Putra : Analisis Pengaruh Pemasangan Dynamic... p-ISSN:1693 - 2951; e-ISSN: $2503-2372$ 